
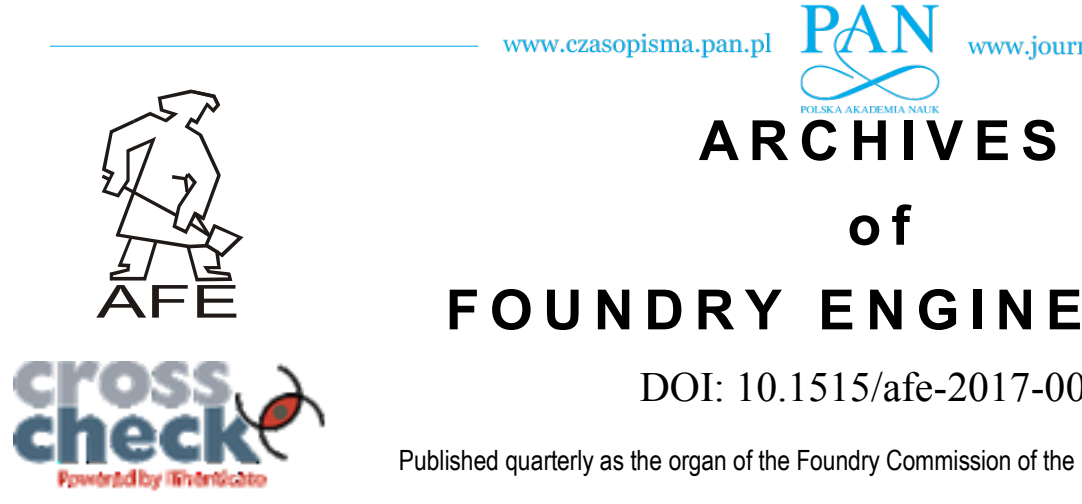

ARCHIVES

\title{
Identification Odor Compounds Emitted During the Heating of Molding Sands
}

\author{
J. Faber *, K. Perszewska \\ Foundry Research Institute \\ ul. Zakopiańska 73, 30-418 Kraków, Poland \\ * Corresponding author. E-mail address: janusz.faber@iod.krakow.pl
}

Received 14.07.2016; accepted in revised form 28.09.2016

\begin{abstract}
The paper presents the results of analyzes of gases emitted during exposure to high temperature foundry molding sands, where binders are organic resins. As a research tool has been used special gas chromatograph designed to identify odorous compounds including the group of alkanes.
\end{abstract}

Keywords: Foundry binders, Odor, Molding sand, Core, Thermal decomposition, Gas chromatography

\section{Introduction}

Currently used in the production of foundry molding and core binders contain ever less dangerous to humans and the environment of organic compounds. As a result, decrease the amount of harmful or toxic compounds emitted into the environment during the production of castings.

It should be noted that, in the emitted gases that are released by the action of high temperature on the weight of the molding materials, and also may include substances that do not occur in the composition of the starting binder. Such compounds may also be issued at lower temperatures, for example during cooling casting or stamping, becoming a source of gaseous effluents and foul smells [3].

Greenhouse gas resulting from the thermal decomposition of chemical compounds contained in the casting molds are often the source of foul smells plaguing local residents, and therefore binders based on organic compounds are increasingly being replaced by much less harmful to people and the environment inorganic substances.

Due to their favorable physical and chemical properties are still among the most commonly used organic binders are furan and phenolic resins. All furan resins comprise the furfuryl alcohol as a monomer or polymer. These may be introduced by other chemical compounds such as urea, formaldehyde, phenol and derivatives thereof, depending on the desired properties of the resin, which results in both of varied composition, although similar in reception odor emitted gases. For the proper mechanical strength of the masses should be made thereto curing agents which are generally sulfonic acids or esters [4].

\section{Emissions at ambient temperature}

From the published studies [4] it shows that due to the low vapor pressure at ambient temperature during the preparation of moulds and cores with the participation of resins chemosetting emission of toxic compounds and odoriferous, such as phenol, formaldehyde or furfuryl alcohol is low or absent. 


\section{Emission of the compounds released from molding sand by the action of heat}

Pouring casting and core hot metal causes that the organic compounds act as binders, molding materials or coatings are degraded thermally.

The chemical composition of the substance is determined if the emitted gases contain organic and / or inorganic. As analyzes in the process of thermal decomposition commonly used in foundry resins most often they can be released water vapor, $\mathrm{CO}$, $\mathrm{CO}_{2}, \mathrm{NH}_{3}, \mathrm{HCN}, \mathrm{SO}_{2}, \mathrm{H}_{2} \mathrm{~S}, \mathrm{PH}_{3}$, phenol formaldehyde, benzene, toluene, ethylbenzene, xylene, isocyanates, polycyclic hydrocarbons aromatic (PAHs), dioxins and furans and other $[1$, $2,4,5,11,13,19]$.

The composition and amount emitted gases depends on the percentage of components organic substances and water, and the temperature. The resulting gases in the largest quantities are: water vapor, carbon monoxide and dioxide, nitrogen oxides, and in much smaller quantities as different organic substances, including fragrances giving them a distinctive scent, often perceived as unpleasant.

Besides the above-mentioned water vapor, carbon oxides and nitrogen depending on the type used for the preparation of the molding and core binders releasing compounds have the characteristic of those resins used in foundry [4, 14]:

Table 1.

Emission of compounds during the decomposition of different bindersused sand molds and core [4]

\begin{tabular}{lcc}
\hline Compound & \multicolumn{2}{c}{ Emission [g/kg binder] } \\
\cline { 2 - 3 } & min. & max. \\
\hline ammonia & 0.04 & 10.931 \\
\hline Hydrogen sulfide & 0.009 & 1.462 \\
\hline nitrogen oxides & 0.012 & 0.372 \\
\hline Sulphur dioxide & 0.036 & 15.107 \\
\hline benzene & 0.648 & 11.209 \\
\hline formaldehyde & 0.01 & 0.257 \\
\hline hydrogen cyanide & 0.029 & 1.184 \\
\hline m-xylene & 0.094 & 2.227 \\
\hline naphthalene & 0.005 & 0.04 \\
\hline o-xylene & 0.03 & 0.729 \\
\hline phenol & 0.024 & 3.904 \\
\hline toluene & 0.121 & 8.825 \\
\hline aromatic amines & 0.049 & 1.275 \\
\hline
\end{tabular}

Comprehensive analysis of the composition of the gases emitted during the process of casting show the presence of approx. 330 different compounds [6, 20], part of which has a peculiar odor.

Listed below are examples of the results of analysis of gases evolved during a casting molds produced using various organic binders [2]. They have been identified in these compounds having the prescribed exposure limit values (MAC) for the job.
Table 2.

The results analysis of gases released during casting molds [2]

\begin{tabular}{|c|c|c|c|c|}
\hline $\begin{array}{l}\text { Com- } \\
\text { pound }\end{array}$ & $\begin{array}{r}\text { MAC } \\
{\left[\mathrm{mg} / \mathrm{m}^{3}\right]}\end{array}$ & $\begin{array}{l}\text { Mouldin } \\
\text { g with } \\
\text { pheno } \\
\text { lic resin } \\
{\left[\mathrm{mg} / \mathrm{m}^{3}\right]}\end{array}$ & $\begin{array}{l}\text { Mould ing } \\
\text { with a } \\
\text { phenol } \\
\text { formaldeh } \\
\text { yde resin } \\
{\left[\mathrm{mg} / \mathrm{m}^{3}\right]}\end{array}$ & $\begin{array}{l}\text { Mouldin } \\
\text { g with } \\
\text { resin } \\
\text { Nova } \\
\text { nol } 165 \\
{\left[\mathrm{mg} / \mathrm{m}^{3}\right]}\end{array}$ \\
\hline $\begin{array}{l}\text { ethane + } \\
\text { ethene }\end{array}$ & - & $<0.01$ & $<0.01$ & $<0.01$ \\
\hline $\begin{array}{c}\text { propane }+ \\
\text { propene }\end{array}$ & $1800-2000$ & $<0.01$ & $<0.01$ & $<0.01$ \\
\hline i-butane & 50 & 0.01 & $<0.01$ & 0.00 \\
\hline n-butane & 1900 & 0.00 & 0.00 & 0.15 \\
\hline i-pentane & 100 & 0.01 & 0.01 & 0.01 \\
\hline n-pentane & 3000 & 0.09 & 0.09 & 0.03 \\
\hline $\begin{array}{l}2,2 \text { di- } \\
\text { metylo - } \\
\text { butane }\end{array}$ & 400 & 0.00 & 0.00 & 0.00 \\
\hline $\begin{array}{l}2, \text { metylope } \\
\text { ntane }\end{array}$ & 400 & 0.00 & 0.00 & 0.35 \\
\hline $\begin{array}{l}\text { 3-metylo- } \\
\text { pentane }\end{array}$ & 400 & 0.00 & 0.00 & 0.00 \\
\hline n-hexan & 72 & 0.00 & 0.00 & 0.00 \\
\hline $\mathrm{CO}_{2}$ & 9000 & 18.30 & 24.03 & 7.53 \\
\hline $\begin{array}{c}\text { nitrogen }+ \\
\text { oxygen } \\
{[\mathrm{ppm}]}\end{array}$ & - & 57.66 & 64.96 & 80.28 \\
\hline methane & - & 0.27 & 4.71 & 0.08 \\
\hline $\begin{array}{c}\text { Carbon } \\
\text { monoxide }\end{array}$ & 23 & 30.43 & 18.43 & 16.39 \\
\hline Hydro gen & - & 1.12 & 0.35 & 0.39 \\
\hline
\end{tabular}

For the foregoing analysis, it shows that above organic compounds present in the gases emitted in very low concentrations by several orders of magnitude lower than their MAC value. Their occurrence in these amounts does not pose a health hazard, but some of them can give them a smell, especially in combination with other odorous compounds.

The results of analyzes of the compounds from the group of BTEX in the flue pyrolysis released from molding sand by the action of heat indicate that these are issued in the largest quantities, benzene and toluene, ethylbenzene and xylenes are present in much smaller quantities $[7,11]$.

\section{Research}

In order to identify organic flavor compounds which are released from the molding material during operation on the high temperature gas samples. Olfactometric qualitative analysis are released gases were conducted by gas chromatography [15] using a portable equipment $z$ Nose ${ }^{\circledR} 4300$ dedicated to the detection of flavor compounds from the group of alkanes (ie. "e-nose") $[8,16$, 17].

For the analysis of odoriferous compounds of degradation products selected molding sands prepared with the participation of seven resins: Supereko (Prec-Odlew sp. z o.o), Kaltharz X850 
(Huettenes Albertus Chemische Werke), Kaltharz XA 20 (Huettenes Albertus Chemische Werke), Furanol FR-75 (PrecOdlew sp. z o.o), Novanol 165 (ASK Chemicals), Modofen (Ciech S.A.) and FRN 100 (SQ Polska) commonly used in foundries.

\subsection{Measuring station}

For the examination of aromatic compounds contained in gases emitted from the above molding material as a result of thermal decomposition furnace was used to test levels of an volume of gases arising during heating molding. This is a quartz tube furnace with an electrically heated in a controlled manner with regard to $1100{ }^{\circ} \mathrm{C}$, with the stabilization of the target temperature.

Samples of the rate of $1 \mathrm{~kg}$ were prepared in a laboratory in accordance with commonly used recipes. For heated to a $1000^{\circ} \mathrm{C}$ furnace tube was introduced $1 \mathrm{~g}$ fresh molding sand containing the tested binders, and passed odorless and non-reactive carbon dioxide at low pressure in order to push the separated gases into a glass flask, where it was collected for testing. Pyrolysis binders took place in conditions of limited supply of air, as is the case in casting molds.

Gas collected in the flasks were analyzed by gas chromatograph specialized $\mathrm{zNose}{ }^{\circledR} 4300$ intended for the selective analysis of fragrance.

\subsection{Olfactomertic analysis}

To identify compounds emitted in the gassing and core sand mold was used a portable gas chromatograph selective $z$ Nose ${ }^{\circledR}$ 4300. This device is for the detection, analysis and identification of more than 700 organic compounds described and their associated scents. These are compounds belonging to the group of alkanes having carbon chain C6-C22 present in concentrations of $\mathrm{ppm}$ and $\mathrm{ppb}$ contained in a specialized database Chemical Library (Kovate Indices 700)

Since the apparatus identifies only the aroma compounds from the group of alkanes, and therefore gas in the test samples are listed only those compounds occurring in them.

They are summarized below and characterized in terms of odor nuisance and health (if any) compounds in quantities of more than $200 \mathrm{cts}$, wherein cts is a quantitative measure of chemicals associated with their odors.

Analysis shows that three of the identified compounds are emitted during the thermal decomposition of all the resins tested, three more are common to the four resins, and another one for the other three

Table 3 summarizes the results of the analysis of gases released during thermal decomposition molding involving these binders, for occurring in those aromatic compounds from alkanes.

Present in the analyzed samples of individual compounds belonging to the alkanes are characterized by smells of phenolicwax-smoky. The smell of resultant, people experience the present state of knowledge it is not possible to predict the results of the analysis, because it is not fully understood mechanism mixing of fragrances [8].

\section{Conclusions}

Since the measuring apparatus identifies compounds based on indexes Kovatsca and assigns the compounds of similar index values different odors, so as a result of multiple analyzes of samples and comparisons diagnosed compounds that appearing in the largest quantities (concentrations) are the most likely impact on the subjective perception of smell accident.

The samples analyzed gases in relatively large quantities were found fifteen aromatic compounds from alkanes wherein identified:

- $\quad$ in seven samples of phenol (smell of phenol); 2-furfuryletantioat (the smell of burning sulfur); benzoic acid (smell of formaldehyde, urine); cresol (odor of phenol, medical)

- $\quad$ in four samples: skatole (smell of faeces, mothballs), lauryl alcohol (the smell of wax, fat); syringol (odor of phenol, smoke); perhydrofarnezyloaceton (smell of fat).

These compounds are present in the samples at levels significantly higher compared to other compounds in the mixture. To date, they are not precisely known and explained the mechanisms governing the recognition of odors being a mixture of aromatic compounds. It is understood $[8,9]$ that the feeling of the resultant gas mixture responsible smell are those that have a low threshold of olfactory and those that are present in greatest concentration. However, based on the identified individual odors of the compounds can not uniquely determine the odor mixtures thereof [10].

In many cases, perceived odor of a single compound is dependent on its concentration, for example skatole in high concentrations has a repulsive odor of feces, while low has a pleasant floral scent and is used for perfumery.

Based on its own work and observations in the vast majority of the compounds tested their concentration occurring in the relative amounts of less than $200 \mathrm{cts}$ their smell is imperceptible or very poor, while undoubtedly is related to the size of their olfactory threshold, which for most compounds is uncertain.

Attention is clear that, in the case of compounds which are known thresholds olfactory and certain size MAC detection threshold is much lower (4 times in the case of cresol and 50-fold in the presence of phenol) than the allowable concentration in the environment or working environment.

The gases emitted in the process of thermal decomposition of the organic binders tested include the trace amounts of aromatic compounds suitable for the characteristic odor, which is dominated in all cases phenolic-smoky smells, doped with odor of urine in the case of a resin comprising urea. These organic compounds give the resultant odor of described as unpleasant and oppressive.

It should be emphasized that during the pyrolytic decomposition of molding sands containing organic binders in the largest quantities released water vapor, carbon oxides, nitrogen, and identified organic fragrances in the present quantities do not have harmful effects for health, although some of them are referred to as harmful or dangerous substances. In most these substances, also do not have thresholds olfactory. 
The practical use of research results may help to reduce odor nuisance gases that are released during pyrolysis molding binders, eg. by minimizing or eliminating some of the ingredients used in resins.

Table 3.

Results of the analysis of the gases from the pyrolysis of a variety of foundry binders

\begin{tabular}{|c|c|c|c|c|c|}
\hline Resins & Odor compound & Odor & $\begin{array}{l}\text { Odor } \\
\text { threshold } \\
{\left[\mathrm{mg} / \mathrm{m}^{3}\right]}\end{array}$ & $\begin{array}{c}\mathrm{MAC} \\
{\left[\mathrm{mg} / \mathrm{m}^{3}\right]}\end{array}$ & COMMENTS \\
\hline $\begin{array}{l}\text { KALTHARZ } \\
\text { X850 } \\
\text { FURANOL FR75 } \\
\text { FRN } 100 \\
\text { MODOFEN OD } \\
\text { NOVANOL } 165 \\
\text { SUPEREKO } \\
\text { KALTHARZ } \\
\text { XA20 }\end{array}$ & $\begin{array}{l}\text { phenol } \\
\text { 2-furfurylethanol- } \\
\text { tioat } \\
\text { benzoic acid } \\
\text { cresol }\end{array}$ & $\begin{array}{l}\text { phenolic } \\
\text { burning } \\
\text { formaldehyde } \\
\text { phenolic }\end{array}$ & 0.156 & 7.81 & $\begin{array}{l}\text { Listed fragrances are present in all } \\
\text { tested resins, other compounds, } \\
\text { specific to particular types of binders } \\
\text { is given with them }\end{array}$ \\
\hline $\begin{array}{l}\text { KALTHARZ } \\
\text { X850 }\end{array}$ & $\begin{array}{l}\text { styrene } \\
\text { skatole } \\
\text { lauryl alcohol } \\
\text { p-hydroxy } \\
\text { ethylbenzene } \\
\text { octadecanol }\end{array}$ & $\begin{array}{l}\text { gasoline } \\
\text { faeces } \\
\text { wax } \\
\text { phenolic } \\
\text { olive }\end{array}$ & $\begin{array}{c}1.38 \\
0.0031 \\
0.4-2.6\end{array}$ & 50 & $\begin{array}{l}\text { In the sample are a predominant } \\
\text { amount of aromatic compounds: } \\
\text { benzoic acid, skatole, lauryl alcohol }\end{array}$ \\
\hline FURANOL FR75 & $\begin{array}{l}\text { skatole } \\
\text { lauryl alcohol } \\
\text { perhydrofarnezylo- } \\
\text { acetone } \\
\text { syringol }\end{array}$ & $\begin{array}{l}\text { faeces } \\
\text { wax } \\
\text { fat } \\
\text { smoky }\end{array}$ & 0.0031 & & $\begin{array}{l}\text { In the sample are a predominant } \\
\text { amount of aromatic compounds: } \\
\text { benzoic acid, lauric alcohol }\end{array}$ \\
\hline FRN 100 & $\begin{array}{l}\text { methylpentane } \\
\text { styrene } \\
\text { p-cresol } \\
\text { lauryl alcohol } \\
\text { syringol }\end{array}$ & $\begin{array}{l}\text { mint } \\
\text { gasoline } \\
\text { phenolic } \\
\text { wax } \\
\text { smoky }\end{array}$ & 1.38 & 50 & $\begin{array}{l}\text { In the sample are a predominant } \\
\text { amount of aromatic compounds: } \\
\text { benzoic acid, lauric alcohol, syringolu }\end{array}$ \\
\hline MODOFEN OD & $\begin{array}{l}\text { skatole } \\
\text { lauryl alcohol } \\
\text { perhydrofarnezylo- } \\
\text { acetone } \\
\text { p-hydroxy } \\
\text { ethylbenzene } \\
\text { syringol }\end{array}$ & $\begin{array}{l}\text { faeces } \\
\text { wax } \\
\text { fat } \\
\text { phenolic } \\
\text { smoky }\end{array}$ & $0.4-2.6$ & & $\begin{array}{l}\text { In the sample are a predominant } \\
\text { amount of aromatic compounds: } \\
\text { benzoic acid, lauric alcohol, } \\
\text { perhydrofarnezylo-acetone }\end{array}$ \\
\hline NOVANOL 165 & p-crezol & phenolic & 1.2 & 5 & $\begin{array}{l}\text { Very small concentrations of all } \\
\text { compounds }\end{array}$ \\
\hline SUPEREKO & $\begin{array}{l}\text { p-crezol } \\
\text { cedrenol }\end{array}$ & $\begin{array}{l}\text { phenolic } \\
\text { wood }\end{array}$ & 1.2 & 5 & $\begin{array}{l}\text { Small concentrations of all } \\
\text { compounds }\end{array}$ \\
\hline $\begin{array}{l}\text { KALTHARZ } \\
\text { XA20 }\end{array}$ & $\begin{array}{l}\text { o-cresol } \\
\text { furfuryl alcohol } \\
\text { phenylacetaldehyde } \\
\text { p-cresol } \\
\text { stearyl alcohol }\end{array}$ & $\begin{array}{l}\text { phenolic } \\
\text { burning } \\
\text { hawthorn } \\
\text { phenolic } \\
\text { olive }\end{array}$ & 1.2 & 30 & $\begin{array}{l}\text { In the sample are a predominant } \\
\text { amount of aromatic compounds: } \\
\text { furfuryl alcohol, phenylacet-aldehyde, } \\
\text { cresol }\end{array}$ \\
\hline
\end{tabular}

\section{Acknowledgements}

This article was created as a result of work funded by the Research Fund of Own Foundry Research Institute in Cracow.

\section{References}

[1] Siewiorek, A., Nowak, R., Chojecki, A. \& Mocek, J. (2011). Gas evolution rate from heated moulding sands bonded with organic binders. Archives of Foundry Engineering. 11(1), 8792.

[2] Samociuk, B., Granat, K., Nowak, D. \& Pigiel, M. (2013). Research gases produced in the oven utilization molding. 
Part 1. Archives of Foundry Engineering. 13(spec.1), 159162. (in Polish).

[3] IPPC: Reference Document on Best Available Techniques in the Smitheries and Foundries Industry, Sewilla 2004

[4] Collective work under the direction of. M. Holtzer (2004). Guide to the best available techniques (BAT) - Guidelines for the foundry industry - Kraków. (in Polish).

[5] Loch, J., Grabowska, B. \& Kaczmarska, K. (2013). BTEX Emissions from BioCo2 Bonded Moulding Sands. Metallurgy and Foundry Engineering. 39(1), 25-31.

[6] Rissom, Ch. (2005). Analyse und Bewertung von Geruchsstoffen in Gießereien - Abschlussarbeit PGS Toxikologie. Freiberg.

[7] Żymankowska-Kumon, S. (2014). Gas chromatographic pyrolysis binders in foundry. Archives of Foundry Engineering. 14(spec.4), 149-152. (in Polish).

[8] Delahunty, C.M., Eyres, G. \& Dufour, J-P. (2006). Gas chromatography - olfactometry, J. Sep. Sci. 29, 2107-2125.

[9] Faber J., Latała-Holtzer M., Perszewska K., Żmudzińska M. (2010). Identification of odors from casting processes using e-nose. Archives of Foundry Engineering. 10 (spec.2), 39-42. (in Polish).

[10] Kośmider, J., Mazur Chrzanowska, B., Wyszyński, B. (2002). Odors. PWN, W-wa (in Polish).

[11] Collective work - The effect of addition regenerate on the quality of castings and harmfulness of molding and core of a new generation. AGH, Kraków 2015.

[12] Watson, G.W., Staples, E.J., Viswanathan, S. (2003). Real Time Odor and VOC Emission Measurements Associated with Environmental Remediation Sites Using a GC/SAW, Air and Waste Management Annual Conference, June 22-26, San Diego, California.
[13] Holtzer, M., Dańko, R., Dańko, J., Kubecki, M., Żymankowska-Kumon, S., Bobrowski, A., Spiewok, W. (2013). Evaluation of the harmfulness of binding material used for molding and core of a new generation. Kraków. Kraków: Wydawnictwo Naukowe Akapit. ISBN: 978-8363663-19-3. (in Polish).

[14] Lewandowski, J.L. \& Solarski W. Classification of molding and core in terms of toxicity. Przeglad Odlewnictwa. 44, 115-123. (in Polish).

[15] Sówka I. (2011). Methods for identification of odorgenerating gases emitted from industrial facilities. Prace Naukowe Instytutu Inżynierii Środowiska Politechniki Wrocławskiej 90. Wrocław: Oficyna Wydawnicza Politechniki Wrocławskiej. 49-54 (in Polish).

[16] Meciarova L., Vilcekova S. \& Balintova M. (2014). Measurement of VOCs with a portable GC/SAW detector. Chemical Engineering Transactions. 40, 283-288. DOI: 10.3303/CET1440048.

[17] Staple E.J., Detection of Phenol in Water and Air Using the zNose $^{\mathrm{R}}$, http://www.estcal.com/TechPapers/Environmental/ Phenol.doc

[18] Bazemore R., Off-Odor Detection Utilizing Gas Chromatography-Mass Spectrometry/Olfactometry (GCMS/O), Volatile Analysis Technical note. Volatile Analysis Corporation - Huntsville, AL - USA.

[19] Staples E., Zeiger K. On-site Measurement of VOCs and Odors from Metal Casting Operations Using an Ultra-Fast Gas Chromatograph. www.estcal.com/TechPapers/Industrial/FoundryOdors.doc

[20] National Occupational Health and Safety Commission, Foundry Health Hazards, Australian Government Publishing Service Canberra, December 1989. 